\title{
Mirasın İntikali ve Rızâî-Kazâî Taksim Konusunda İslâm Hukuku ile Türk Medeni Kanunu'nun Karşılaştırılması
}

\author{
Mehmet Sait ARVAS*
}

Atıf/Cite as: Arvas, Mehmet Sait. "Mirasın İntikali ve Rızâî-Kazâî Taksim Konusunda İslâm Hukuku ile Türk Medeni Kanunu'nun Karşılaştırılması" Recep Tayyip Erdoğan Üniversitesi İlahiyat Fakültesi Dergisi 20 (2021), 89-112.

\section{Öz}

Kişi öldüğünde geride bıraktığı mal varlığına bazı haklar taalluk etmektedir. Bunlardan biri de mirastır. Murisin ölümüyle birlikte mirasın mülkiyeti vârislerine intikal etmektedir. Miras mülkiyeti, vârislerin birden fazla kişi olmaları halinde zorunlu ortaklık olarak başlamakta ve mirasın paylaşılmasıyla şahsi mülkiyete intikal etmektedir. Bu da vârisler arasında uzun soluklu ilişkiler ağını doğurmaktadır. Hukuk sistemleri bu ilişkiler ağında taraflar arasında doğabilecek olası uyuşmazlıkların önüne geçmek için miras hukukuyla ilgili ayrıntılı düzenlemelere yer vermektedir. İslâm hukukunda da mirasla ilgili birçok ayrıntılı hüküm önemine binaen nasla düzenlenmiştir. Bu nedenle İslâm miras hukuku birçok çalışmaya konu edilmekte ve diğer hukuk sistemleriyle karşılaştırılmaktadır. Bu çalışmada ise İslâm hukukuna göre mirasın intikali ve rızâî-kazâî açıdan paylaşılması ele alınmaktadır. Bunun yanında çalışmada konuyla ilişkili meseleler bağlamında İslâm hukuku ile Türk Medeni Kanunu arasında karşılaştırmaya gidilmektedir. Çalışma, biri mirasın intikali, diğeri ise rızâî-kazâî açıdan paylaşılması olmak üzere iki bölümden oluşmaktadır. Son olarak çalışmada iki hukuk sisteminin karşılaştırıldığ genel değerlendirme ve sonuca yer verilmektedir.

Anahtar Kelimeler: İslâm Hukuku, Türk Medeni Kanunu, Mirasın İntikali, Miras Ortaklığı, Rızâî Taksim, Kazâî Taksim.

* Dr. Öğr. Üyesi, Recep Tayyip Erdoğan Üniversitesi, Rize, Türkiye, mehmetsait.arvas@erdogan.edu.tr, ORCID: www.orcid.org/0000-0003-0303-1550 
90 RTEÜ̈r㠯

\title{
The Comparison between Islamic Law and Turkish Civil Code on Acquisition of Inheritance and İts Division by Voluntary or Judiciary
}

\begin{abstract}
When a person dies, certain rights arise over her remaining property. One of them is inheritance. Upon the death of the inheritor, inheritance property descends his heirs. The inheritance property begins as a compulsory partnership if the heirs are more than one person and then it is transferred to personal property with the division of the inheritance. This creates a long-term relationship network between the heirs. Legal systems include detailed regulations on inheritance law in order to prevent possible disputes that may arise between the parties in this network of relations. In Islamic law, many detailed provisions relating to inheritance are regulated in accordance with the Qur'an and the Sunna. For this reason, Islamic inheritance law has been the subject of many studies and compared to other legal systems. In this study, acquisition of inheritance and its division by voluntary or judiciary are discussed within the scope of Islamic law. In addition to this, a comparison between Islamic law and Turkish Civil Law is made in the context of issues regarding to the issue. The study consists of two parts, one of which is the acquisition of inheritance and the other is its division by voluntary or judiciary. Finally, the general evaluation and conclusion in which the two legal systems are compared are given in the study.
\end{abstract}

Keywords: Islamic Law, Turkish Civil Code, Acquisition of Inheritance, Inheritance Partnership, Voluntary Division, Judicial Division.

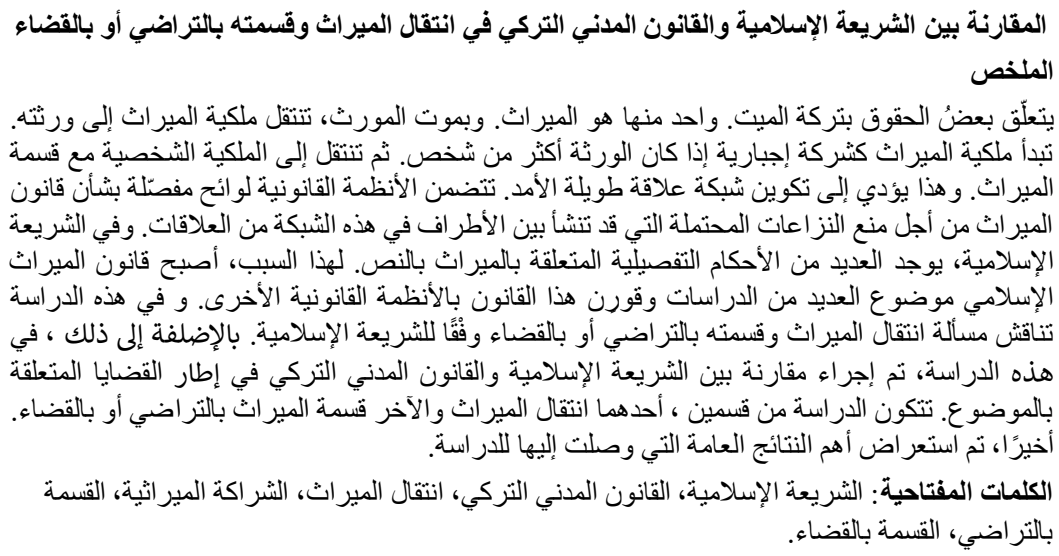

\section{GíRiş}

Miras yoluyla mülkiyetin kazanılması, vârislerin birden fazla kişi olmaları halinde vârisler arasında birçok hukuki işlem ve ilişkinin yaşanmasını zorunlu kılmaktadır. Murisin ölmesiyle geride bıraktığı malvarlığı (tereke), terekeye taalluk eden haklar, tereke üzerindeki mülkiyetin vârislere intikal etmesi, miras ortaklığı ve 
mirasın paylaşılması bunlardan bazıları olarak zikredilebilir. Hal böyle olunca hukuk sistemleri de bu ilişkiler silsilesinde ortaya çıkması muhtemel birçok anlaşmazlığı önlemek için ayrıntılı kurallar vaz' etmektedir. Günümüz hukuk sistemlerinde bu işlem ve ilişkiler silsilesi bir bütün halinde miras hukuku adı altında incelenmektedir. ${ }^{1}$ İslâm hukuk kaynaklarında ise mirasın maddi olarak paylaşılması dışındaki diğer süreçlerin miras hukuku anlamına gelen "ferâiz" bölümünde incelendiği, mirasın paylaşılmasının ise diğer bütün müşterek malların paylaşılmasıyla birlikte "kısmet" 2 bölümünde ele alındığı görülmektedir. Dolayısıyla miras üzerindeki mülkiyetin vârislerin tamamına intikali, böylece miras ortaklığının oluşması ve nihayet mirasın paylaşılması ile de şahsi mülkiyete intikal etmesi süreçlerinin İslâm hukuku açısından bir bütün halinde incelenmesi önem arz etmektedir. İşte bu amaçla makalede İslâm hukukunda mirasın intikali ve rızâî-kazâî açıdan paylaşılması konu edilmektedir. Ancak konuyla ilişkili mezhepler arası ihtilaflar amaçlanmadığından çalışmada Hanefi mezhebinin uygulaması esas alınmakta diğer mezheplere ait farklı uygulamalara ise yer yer dipnotlarda işaret edilmektedir.

Çalışmada amaçlanan bir diğer husus İslâm hukuku açısından rızâî-kazâî taksimin mahiyetinin ortaya konulmasıdır. $\mathrm{Bu}$, hem söz konusu taksim türlerinin mirasın paylaşımıyla ilişkili hukuki süreci ifade etmesi hem de rıâ̂îkazâî taksimin eksik veya yanlış anlaşılması sebebiyle nasların emredici ve kesin hükümlerine karşılık vârislerin anlaştıkları takdirde mirası diledikleri şekilde düzenleyebilecekleri gibi hatalı algılamaları önlemek amacıyla tercih edilmektedir. Çalışmada, bütün çeşitleriyle paylaşma usulünün incelenmesi amaçlanmadiğından tefrik ve cem' taksim $^{3}$ türlerine yer verilmemektedir.

Çalışmada ayrıca mirasın intikali ve paylaşılma süreçleriyle ilişkili İslâm hukuk uygulamasının, 4721 sayılı ve 2001 tarihli Türk Medeni Kanunun (TMK)

14721 sayılı Türk Medeni Kanunu 3. kitapta 495. maddeden 682. maddeye kadar 187 madde içinde miras hukuku ilişkilerini düzenlemiştir. Ayrıca bk. Ali Naim İnan vd., Türk Medeni Hukuku Miras Hukuku (Ankara: Bilge Yayınevi, 2015); Rona Serozan - Baki İlkay Engin, Miras Hukuku (Ankara: Seçkin Yayıncılık, 2014).

2 Alâüddin Ebû Bekr b. Mes'ûd b. Ahmed el-Kâsânî, Bedâ'i'u's-sanâ'i' fî tertîbi'ş-şerâ'i', thk. Ali Muhammed Muhammed Muavvaz - Adil Ahmed Abdülmevcud (Beyrut: Darü'l-Kütübi'lİlmiyye, 1424/2003), 9/141; Ebü'l-Velîd Muhammed b. Muhammed b. Ahmed b. Rüşd el-Kurtubî, Bidâyetü'l-müctehîd ve nihâyetü'l-muktesıd, thk. Heysem Cum'a Hilâl (Beyrut: Müessesetü'l-Meârif, 1427/2006), 681; Ebû Zekeriyyâ Yahyâ b. Şeref b. Mürî en-Nevevî, Ravzatü't-tâlibîn ve 'umdetü'lmütteakîn, thk. Adil Ahmed Abdülmevcût - Ali Muhammed Muavvez (Suud: Dâr-1 Âlemi'l-Kütüb, 1423/2003), 8/181; Zeynüddîn Mer'î b. Yûsuf el-Kermî, Delîlü't-tâlib li neyli'l-metâlib (b.y.: elMektebetü'l-İslâmî, 1389/1969), 341; Hamza Aktan, "Kısmet”, Türkiye Diyanet Vakfi İslâm Ansiklopedisi (Ankara: TDV Yayınları, 2002), 25/497-498.

3 Tefrik ve cem' taksim tanımları için "Mirasın Rızâî-Kazâî Açıdan Paylaşılması” bölümüne bakınız. 
92 Mirasın İntikali ve Rıâ̂i-Kazâî Taksim Konusunda İslâm Hukuku ile Türk Medeni Kanunu'nun Karşılaştırılması

uygulamasıyla mukayesesi amaçlanmaktadır. ${ }^{4}$ Bu mukayese, konuyla ilişkili kavram ve müesseselerin daha anlaşılır olmasına katkı sağlaması ve ülkemizde câri olan hukuk sistemi olması nedenleriyle tercih edilmektedir.

Makale iki bölüm ile genel değerlendirme ve sonuçtan oluşmaktadır. Mirasın intikali başlıklı birinci bölümde terekeye taalluk eden haklar, mirasın intikali, miras ortaklığı ve türü ele alınmaktadır. İkinci bölümde ise mirasın paylaşılma yollarına yer verilmektedir. Mirasın intikali ve paylaşımıyla ilgili hukuk sistemlerinin uygulama bütünlügünü sağlamak amacıyla her bölüm önce İslâm hukuku daha sonra Türk Medeni Kanunu başlıklarıyla ayrı ayrı ele alınmaktadır. Son olarak genel değerlendirme ve sonuç kısmında ise iki hukuk sistemi arasındaki uygulama farklılıklarına temas edilmektedir.

Makalede başta Hanefi mezhebine ait olmak üzere klasik fıkıh kitapları, Mecellei Ahkâm-ı Adliyye ve Ali Haydar Efendi'nin Mecelle şerhi olan Dürerü'l-hükkâm'ı ile günümüz araştırmacılarının miras hukuku ve taksimle ilgili yazdıkları kitap, tez, makale ve ansiklopedi maddeleri kaynak olarak kullanılmaktadır. Güncel çalışmalardan özellikle Hamza Aktan'a ait Mukayeseli İslâm Miras Hukuku adlı kitap ve Adnan Koşum'a ait İslâm Hukukunda Taksim adlı yüksek lisans çalışması ${ }^{6}$ önemli ölçüde yararlanılan kaynaklardandır. Hamza Aktan'a ait çalışma miras hukuku ve mirasın paylaşılması (kısmet) konularının tamamını ele alması açısından önemli bir boşluğu doldurduğu söylenebilir. Bu makalenin ise İslâm hukukuna ait uygulamanın Türk Medeni Kanunu'yla mukayese edilmesi ve rızâî-kazâi taksimle ilgili yukarıda ifade edilen yanlış düşünceleri önlemeyi amaçlaması açısından önem arz ettiği ifade edilebilir.

Türk miras hukukuna ait kısımda ise kaynak olarak 4721 sayılı ve 2001 tarihli Türk Medeni Kanunu ile miras hukuku ve medeni hukuka dair yazılan kitap, tez ve makalelerden yararlanılmaktadır.

4 İslâm miras hukukuyla Türk miras hukuku arasında yapılan mukayeseli çalışmalar için bk. Abdurrahman Yazıcı, "Cumhuriyet Dönemi Türkiye'sinde İslâm Miras Hukuku Çalışmaları", İslam Hukuku Araştırmaları Dergisi 22 (2013); Alpaslan Alkış, “İslam Miras Hukuku ile Türk Miras Hukukunun Varisler Yönüyle Karşılaştırılması”, Çukurova Üniversitesi İlahiyat Fakültesi Dergisi 19/1 (2019), 60-79.

5 Hamza Aktan, Mukayeseli İslâm Miras Hukuku (İstanbul: İşaret Yayınları, 1991).

6 Adnan Koşum, İslâm Hukukunda Taksim (İstanbul: Marmara Üniversitesi, Sosyal Bilimler Enstitüsü, Yüksek Lisans Tezi, 1995). 


\section{Mirasın İntikali}

\section{1. İslâm Hukukuna Göre}

Ölen kişinin, geride bıraktığı ve aynına başkalarının hakkı taalluk etmeyen mallarına tereke denir.7 Ölümüyle birlikte kişinin geride bıraktığı mal varlığı üzerinde bazı haklar terettüp etmektedir. Bunlar sırasıyla teçhiz-tekfin masrafları, borçlar, vasiyet ve mirastır. ${ }^{8}$ Terekeden öncelikle murisin teçhiz-tekfin masrafları ve borçları karşılanır. Bunlardan sonra geriye kalan terekenin 1/3' ünden ${ }^{9}$ murisin vasiyeti yerine getirilir. Son olarak terekenin bakiyesi miras olarak vârislere intikal eder. ${ }^{10}$

Miras mülkiyetinin vârislere intikali halefiyet yoluyla olmaktadır. ${ }^{11}$ Halefiyet, bir şahsın bir başkasının yerine geçmesi anlamına gelen hukukî bir kavramdır. ${ }^{12}$ Buna göre vârislerin miras mülkiyetini kazanmaları, murisin ölümüyle birlikte onun yerine kaim olmalarıyladır.

Miras üzerindeki mülkiyetin ne zaman intikal ettiğine dair kaynaklarda iki farklı görüş zikredilir. Birinci görüş, murisin hayatta olduğu en son anda mirasın vârislere intikal ettiği şeklindedir. Bu görüşe göre mirasın muristen vârislere intikali, canlıdan canlıya olan bir intikal olmaktadır. Bu görüş Züfer (öl. 158/775) ile Irak meşâyihine atfedilmektedir. Diğer görüş ise murisin ölümüyle birlikte mirasın derhal vârislere

7 Ebü'l-Hasen Alî b. Muhammed b. Alî es-Seyyid eş-Şerîf el-Cürcânî el-Hanefî, Şerhu'l-Ferâ'izi'sSirâciyye, thk. Muhammed Muhyiddin Abddulhamid (Mısır: Matbaa Mustafa Elbâbî Mahlebî ve Evladihi, 1323/1944), 4; Muhammed Emîn b. Ömer b. Abdilazîz İbn Âbidîn, Reddü'l-muhtâr ale'dDürri'l-muhtâr, thk. Abdulmecid Ta'me Halebî (Beyrut: Dârü'l-Ma'rife, 1432/2011), 10: 528; Ali Haydar Efendi, Teshîlü'l-Ferâiz, çev. Orhan Çeker (Konya: Tekin Kitabevi ts.), 12-13; Mezheplerin terekenin kapsamına ilişkin görüşleri için bk. Muhammed Ebû Zehre, Ahkâmü't-terikât ve'l-mevârîs (Kâhire: Darü'1-Fikri'l-Arabî, ts.), 42-45; Aktan, Mukayeseli İslâm Miras Hukuku, 62-65; Abdüsselam Arı, İslâm Miras Hukuku (İstanbul: M.Ü. İlahiyat Fakültesi Vakfı Yayınları, 2020), 47-51.

8 Cürcânî, Şerhu'l-Ferâ'izi's-Sirâciyye, 3; Ebü'l-Fazl Abdullah b. Mahmûd b. Mevdûd el-Mevsılî, el-İhtiyâr li ta'lili'l-Muhtâr, thk. Halid Abdurrahman el-Akk (Beyrut: Darü'l-Ma'rife, 1419/1998), 5/104.

9 Vasiyetin, terekenin $1 / 3^{\prime}$ den fazla veya varise yapılması gibi durumlarda varislerin onay1 ile bu vasiyet geçerli olur. Şayet varislerin bir kısmı bunu onaylıyor ise bu durumda onaylayanların hissesine düşen oranda bu vasiyet geçerli olur. Buna rıza göstermeleri durumunda varisler, haklarının bir kısmını ıskat etmiş olmaktadırlar. Burada varislerin mûrisin ölümünden sonra onay vermeleri dikkate alınır. Çünkü mûrisin ölmesiyle birlikte onların miras üzerindeki hakkı sabit olmuş ve böylece onlar haklarından bir kısmını 1skat etmiş olmaktadırlar. Mevsılî, el-i̇htiyâr, 5/7879; Abdülganî b. Tâlib b. Hammâde el-Meydânî el-Guneymî ed-Dimeşkî, el-Lübâb fî şerhi'l-Kitâb, thk. Beşşâr Bekrî Arabî (Dımeşk: Dâr-1 Kubâ', 1424/2003), 706.

10 Cürcânî, Şerhu'l-Ferâ'izi's-Sirâciyye, 7.

11 Mustafa Ahmed ez-Zerkâ, el-Medhalü'l-fikhiyyü'l-âm (Dımeşk: Darü'l-Kalem, 1425/2004), 1/335; Ali el-Hafîf, el-Milkiyye fî'ş-şerîati'l-İslâmiyye maa'l-mukârene bi'ş-şerâii'l-vad'iyye (Kahire: Darü'l-fikri'lArabî, 1996/1416), 327.

12 Halef için bk. Ebü'l-Fazl Cemâlüddin Muhammed b. Mükerrem b. Ali İbn Manzûr, Lisânü'l-Arab, thk. Abdullah Ali el-Kebîr vd. (Kahire: Darü'l-Meârif, 1119), "Halef", 2/1236; Rahmi Yaran, "Halef", Türkiye Diyanet Vakfi İslâm Ansiklopedisi (İstanbul: TDV Yayınları, 1997), 15/ 233-234; Mehmet Erdoğan, Fıkıh ve Hukuk Terimleri Sözlüğ̈̈ (İstanbul: Rağbet Yayınları, 1998), "Halef”, 136. 
94 Mirasın İntikali ve Rıâ̂i-Kazâî Taksim Konusunda İslâm Hukuku ile Türk Medeni Kanunu'nun Karşılaştırılması

intikal ettiği şeklindedir. Bu görüşe göre ise intikal ölüden canlıya doğrudur. Ebû Yûsuf (ö. 182/798), Muhammed eş-Şeybânî (ö. 189/805) ve Belh meşâyihinin bu görüşte olduğu aktarılır. ${ }^{13}$

$\mathrm{Bu}$ ihtilafın her ne kadar bazı farazî örneklerle ${ }^{14}$ semeresi ortaya konulsa da lafzî/teorik bir tartışmadan ibaret olduğu söylenebilir. Yukarıdaki ihtilafın yanında fer'i bazı meselelere etki ettiği görülen bir diğer tartışma murisin borçlu olması durumunda terekenin ne zaman ve ne şekilde vârislere intikal ettiğidir. İslâm miras hukukunda murisin borcu terekeyle sınırlıdır ve bu borç vârislere intikal etmez. ${ }^{15}$ Zira miras, yukarıda da ifade edildiği üzere terekeye taalluk eden teçhiz-tekfin, borç ve vasiyet gibi diğer haklardan geriye kalan kısmı ifade eder.

Murisin borcu tereke mevcudundan fazla yani tereke borca batık ise bu durumda borcun terekeden karşılanması ihtiyacına binaen murisin ölümden sonra da tereke üzerindeki mülkiyetinin hükmen devam ettiği kabul edilir. ${ }^{16}$ Dolayısıyla bu durumda borçtan geriye kalan olmadığından mirastan ve onun intikalinden söz edilemez. ${ }^{17}$

13 Muhammed b. Hüseyin b. Ali et-Tûrî, Tekmiletü'l-Bahri'r-râik, nşr. Muhammed Alî Beyzavî (Beyrut: Darü'l-Kütüb'i-İlmiyye, 1418/1997), 9/364; İbn Âbidîn, Reddü'l-muhtâr, 10/527.

14 Bu ihtilafın semeri olarak verilen örneklerden biri şöyledir: Bir kimse, kendisinden başka varisi olmayan mûrisinin cariyesi ile evlenmiş olsa ve eşine (cariyeye) "Efendin öldüğünde, hürsün." demiş olsa; birinci görüşe (yani canlıdan canlıya intikali kabul edenlere) göre eşi azat olmuş olur. Çünkü cariyenin azat olması efendinin ölümüne bağlanmış ve kocası da efendinin ölümünden hemen önce cariyeye malik olmuştur. İkinci görüşe (ölüden canliya intikali kabul edenlere) göre ise kocanın mülkiyeti ölümden sonra sabit olduğundan cariye azat olmaz. Bk. İbn Âbidîn, Reddü'lmuhtâr, 10/527.

15 Teçhiz ve tekfin masraflarından sonra tereke bakiyesinden murisin borçları ödenir. Şayet tereke, borçların tamamını karşılayacak durumda değilse, alacaklıların her biri alacağını eksik tahsil eder. Alacaklılar kalan alacakları için mirasçlara müracaat edemez. Ancak vâris veya başka biri murisin borcunu ödemeyi üstlenebilir. Eksik kalan alçakları için hak sahipleri ya murisi bağışlar ya da haklarını hesap gününe (dârü'l-bekâ) havale ederler. Bk. Cürcânî, Şerhu'l-Ferâ'izi's-Sirâciyye, 5; Aktan, Mukayeseli İslâm Miras Hukuku, 67.

16 Alaüddin Abdülaziz b. Ahmed b. Muhammed el-Buhârî, Keş̧ü'l-esrâr fì şerhi Usûli'l-Pezdevî, thk. Abdullah Mahmud Muhammed Ömer (Beyrut: Darü'l-Kütübi'l-İlmiyye, 2009), 4/440.

17 Tereke mevcudundan fazla olan borcun, terekenin intikaline engel olduğu ihtilaflıdır. Maliki mezhebi, Hanefilerde olduğu gibi borcun terekenin intikaline engel olduğu görüşündedir. Ahmed b. Hanbel'den (ö. 241/855) aktarılan iki görüşten biri de böyledir. Şafiilere ve Ahmed b. Hanbel'den aktarılan meşhur görüşe göre ise borç ister tereke mevcudunun tamamını kuşatsın ister bir kısmına tekabül etsin ölümle birlikte terekenin tamamının mülkiyeti varislere intikal eder. Borçlar mülkiyetin intikaline engel olmayıp sadece varislerin tereke üzerinde tasarrufta bulunmalarına engel oluşturur. Bk. Şemsüddin Muhammed b. Ahmed el-Hatîb eş-Şirbînî, Muğni'l muhtâc ilâ ma'rifeti me'ânî elfâzi'l-Minhâc, nşr. Muhammed Halil Aytânî (Beyrut: Darü'l-Marife, 1418/1997), 3/8; Ebû Zehre, Ahkâmü't-terikât ve'l-mevârîs, 21-22; Hafîf, el-Milkiyye, 328-330; Aktan, Mukayeseli İslâm Miras Hukuku, 249-250. 
Murise ait borcun tereke mevcudunun bir kısmına tekabül etmesi durumu hakkında Ebû Hanîfe (ö. 150/767) ve Ebû Yûsuf başlangıçta borcun, ölüm anında terekenin tamamı üzerindeki mülkiyetin mirasçılara intikaline engel olduğu görüşüne sahip olmuşlardır. Ancak daha sonra onlar borcun, sadece karşılığı olduğu miktarda terekenin intikaline engel olduğunu, diğer kısımlardaki mülkiyetin ise murisin ölümüyle birlikte vârislere intikaline engel olmadığını benimsemişlerdir. Muhammed eş-Şeybânî de bu görüşü benimsemiştir. ${ }^{18}$

Mirasın vârislere intikali cebrîdir. ${ }^{19}$ Zira miras, tarafların rızalarına veya anlaşmalarına (iradelerine) bağlı olmayarak şer'an/hukuken kendiliğinden oluşan bir haktır. Öyle ki vârislerden birinin "Ben miras hakkımdan vazgeçtim" veya "Ben mirasçı olmayacağım" gibi sadece miras hakkını düşürdüğüne dair irade beyanıyla tevarüs hakkı düşmez. Hatta bu vâris, böyle dedikten sonra henüz miras taksim edilmeden önce vefat etse vârisleri reddettiği terekeden onun hissesini almaya hak sahibi olurlar. ${ }^{20}$ Ancak bağışlama veya satış gibi bir yolla vârisler miras haklarını başkalarına devredebilirler. Bu ise miras hakkını düşürmek (1skat) olmayıp hakkın devri anlamina gelir. ${ }^{21}$

Mirasın intikaliyle birlikte birden fazla kişi olmaları durumunda vârisler arasında cebrî/zorunlu bir ortaklık oluşur. Miras yoluyla oluşan bu ortaklık, mülk ortaklığı olarak kabul edilir.22 Bu ortaklık aynı zamanda şâyi hisseli (paylı/müşterek) bir mülkiyeti ifade eder ki mirasın her cüz'ü ve zerresi, 1/2, 1/3, 1/6 gibi belirlenmiş hisselerle vârislerin hepsine ait olur. ${ }^{23}$

Vârislerin mirastaki hisseleri, nas ve icmâ ile belirlenmiş olup sabit ve kesindir. Zira Nisâ 11. ayette miras hükümleri Şâri` Teâla tarafından emredici olarak düzenlenmiş² ayrıca Nisâ 13 ve 14 . ayetlerde ilgili hükümlere uymanın gerekliliği

18 Ebû Bekr Şemsü'l-eimme Muhammed b. Ebî Sehl Ahmed es-Serahsî, el-Mebsût (Beyrut: Dârü'lMa'rife, ts.), 29/137; Buhârî, Keşfü'l-esrâr, 4/440; Ebû Zehre, Ahkâmü't-terikât ve'l-mevârîs, 18-20.

19 Ebû Zehre, Ahkâmü't-terikât ve'l-mevâris, 5; Zerkâ, el-Medhal, 1/341; Hafîf, el-Milkiyye, 327-329; Muhammed Zekeriyyâ el-Berdîsî, el-Miras (Kahire: Darü'n-Nahda el-Arabî, 1971/1391), 13-14.

20 Ömer Nasuhi Bilmen, Hukuk-ı İslâmiyye ve Istılâhâtı Fıkhiyye Kâmusu (İstanbul: Bilmen Yayınevi, ts.) $8 / 36$.

21 Şâriin düzenlemesini değiştirme anlamı taşıdığından ıskata elverişli görülmeyen mirasçılık hakkına ilişkin ibrâ sahih olmaz. H. Yunus Apaydın, "İbrâ", Türkiye Diyanet Vakfı İslâm Ansiklopedisi (İstanbul: TDV Yayınları, 2000), 21/265; Ali Bardakoğlu, "Iskat", Türkiye Diyanet Vakfı İslâm Ansiklopedisi (İstanbul: TDV Yayınları, 1999), 19/138.

22 Mevs1lî, el-İhtiyâr, 2/440; Mecelle-i Ahkâm-ı Adliyye (İstanbul: Matbaa-i Osmânî, 1300), md. 1060, 1064, 1066, 1092; Ali Haydar Efendi, Dürerü'l-hükkâm şerhu Mecelleti'l-ahkâm (Kostantiniyye: Matbaa-i Ebûzziyâ, 1330), 3/ 332.

23 Bk. Hafîf, el-Milkiyye, 128; Hasan Hacak, "Müşâ'", Türkiye Diyanet Vakfi İslâm Ansiklopedisi (İstanbul: TDV Yayınları, 2006), 32/151-152.

24 Ebû Mansûr Muhammed b. Muhammed b. Mahmûd el-Mâtürîdî, Te'vîlâtü Ehli's-sünne, thk. Mecdî Basellûm (Beyrut: Dârü'1-Kütübi'l-İlmiyye, 1426/2005), 3/37; Ebû'1-Berekât Abdullah b. Ahmed b. 
96 Mirasın İntikali ve Rıâ̂i-Kazâî Taksim Konusunda İslâm Hukuku ile Türk Medeni Kanunu'nun Karşılaştırılması

vurgulanmış, aykırı davranılması ise uhrevi yaptırıma bağlanmıştır. ${ }^{25} \mathrm{Bu}$ da ilgili hükümlerin bütün mükellefler açısından bağlayıcı ve hiçbir şekilde aksine amel edilmeyeceğini gerektirmektedir. ${ }^{26} \mathrm{Bu}$ nedenledir ki İslâm miras hukukunda ne murise ölüme bağlı bir tasarruf olarak mirası düzenleme hakkı tanınmış ne de anlaşmaları durumunda vârislere diledikleri şekilde mirası düzenleme yetkisi verilmiştir. ${ }^{27}$ Ayrıca murisin ölmesiyle kanunen (nas ve icmâ) belirlenmiş hisselerle mirasın derhal vârislere intikal etmesi de vârislere kendilerinin belirleyecekleri bir oranda mirası düzenleyebilme imkânı tanımamaktadır. ${ }^{28}$

Konuya biraz daha açılık getirmek gerekirse vârislerin mirası düzenlemesiyle onların, ferâiz ilminde takdir edilen hisselerle değil de bizzat kendilerinin uzlaşarak belirledikleri paylara göre miras üzerinde hak sahibi olmaları kastedilmektedir. Vârislerin, her bir mirasçının eşit oranda mirasa sahip olacaklarına yönelik düzenlemeleri buna örnek verilebilir. Bu, yukarıda da ifade edildiği üzere nassın beyanına, emredici ve bağlayıcı hükümlerine aykırıdır. Burada vârislerin uzlaşarak maddi anlamda mirası paylaşmalarını ve diledikleri şekilde tasarruf edebilmelerini ifade eden rızâî taksimin, yukarıda kastedilen anlamıyla "vârislerin diledikleri şekilde mirası düzenleme yetkilerinin bulunmadığı" kuralına aykırı olmadığını belirtmek gerekir. Çünkü rızâî taksim farklı bir hukuki aşamayı ifade etmektedir. Şöyle ki mirasın intikali, naslarla belirlenmiş hisselerine göre murisin ölümüyle birlikte cebren ve derhal gerçekleşmektedir. Dolayısıyla vârislerin onayına bağlı olmaksızın miras üzerinde hisseleri belirlenmiş bir ortaklık kendiliğinden oluşmaktadır ki bu, mirasın ilk aşamasıdır (intikal aşaması). İşte bu aşamada vârislerin ferâizde belirlenen hükümler dışında herhangi bir düzenleme yapmaları mümkün değildir. Ancak miras

Mahmud en-Nesefî, Medârikü't-tenzîl ve hakâ'iku't-te'vîl, thk. Yusuf Ali Büdeyvî (Dımeşk: Dâr-1 İbn Kesîr, 1429/2008), 1/ 334.

25 Mâtürîdî, Te'vîlâtü Ehli's-sünne, 3/65; Nesefî, Medârikü't-tenzîl, 1/340.

26 İlgili ayetlerin bağlayıcı ve aksi bir şekilde amel edilemeyeceğine dair ayrıca bk. Hilal Özay, "İslâm Miras Hukukunun Özellikleri", İslam Medeniyeti Araştırmaları Dergisi 3/2 (Aralık, 2018), 208-209; Abdurrahman Yazıcl, "İslam Miras Hukuku ile Türk Medeni Kanunu Miras Sisteminin Mukayesesi", Ekev Akademi Dergisi 17/55 (Bahar 2013), 170.

27 Bk. Şakir Berki, “Kur'an'da Mîrâs Hukuku”, Ankara Üniversitesi Hukuk Fakültesi Dergisi 38/1 (1981), 113, 115-116. Araştırdığımız İslâm Miras hukuku kaynaklarında, varislerin uzlaşmaları durumunda mirası ferâizde belirlenen hisseler dışında diledikleri gibi düzenleyebileceklerine dair bir bilgiye rastlayamadık. Bunun yanında kaynaklarda nas ve icmâ ile düzenlenen miras hisselerinin, değişmez ve sabit bir şekilde belirlendiği açıkça vurgulanmıştır. Örnek olarak bk. Serahsî, el-Mebsût, 29/138; Mevsılî, İhtiyâr, 5/103; Şeyh Nizâm - vd., el-Fetâva'l-Hindiyye, nşr. Muhammed Alî Beyzavî (Beyrut: Darü'l-Kütübi'l-İlmiyye,1421/2000), 6/497.

28 Türk miras hukuku dikkate alındığında İslâm miras hukukundaki uygulama daha iyi anlaşılabilecektir. Şöyle ki MK'da mirasçıların hisseleri belirlenmiş olmakla birlikte bunları düzenleyen kanunlar emredici değildir. Bu nedenledir ki MK'da mirasın mirasçılara intikali, şâyi hisseli değil de elbirliği (iştirak) halinde yani hisseleri belirlenmiş olmaksızın bir mülkiyet şeklinde kabul edilmiştir. Böylece MK mirasçılara kendilerine göre mirası düzenleme imkânı tanımış olmaktadir. 
üzerinde vârislerin şâyi hisseli yani mirasın tamamına yayılan haklarının belli mallara özgülenmesi ihtiyacına binaen mirasın maddi olarak paylaşılması (kısmet) gerekmektedir. İşte bu da söz konusu ikinci aşamayı (paylaşma aşaması) ifade etmektedir. Artık bu aşamada yapılacak işlem miras düzenlemelerinin dışında başka bir hukuki aşama olarak görülür. $\mathrm{O}$ da ortak malın paylaşılması/taksimidir. Dolayısıyla paydaşların bu aşamada anlaşmaları durumunda diledikleri şekilde bir düzenlemede (rızâî taksim) bulunmaları mümkündür. İleride bu konuya tekrar temas edilecektir.

Mirasın paylaşılmasından yani her birinin hissesi belli bir mala özgülenmeden önce vârislerin şâyi hisseli ortak maldaki (mirastaki) hakları şöyle özetlenebilir:

Diğerlerinin izni olmaksızın vârislerden birinin, kendi hissesine denk gelen miktar bile olsa, tereke malları üzerinde bir tasarruf yetkisi bulunmaz. Çünkü ortakların her biri diğer ortağın hissesinde yabancı gibidir, onun vekili veya temsilcisi durumunda değildir. ${ }^{29}$ Terekenin her cüz'ü ve zerresi bütün ortaklara ait olduğundan (şâyi hisse), vârisler ancak ortak hareket ederek tereke malları üzerinde bir tasarrufta bulunabilirler. ${ }^{30}$ Fakat ortaklardan biri, diğer ortakların izni olmaksızın şâyi hissesini diğer bir ortağa veya yabancı birine satabilir. ${ }^{31}$

\subsection{Türk Medeni Kanunu'na Göre}

Tereke, mirasbırakanın, mirasçılara geçen ve parayla ölçülebilen bütün hak ve borçları ile hukuki ilişkilerini ifade eder. Buna aynı zamanda miras denir. ${ }^{32}$

Mirasbirakanın ölümüyle birlikte terekesi kural olarak herhangi bir kabul açıklamasına gerek olmaksızın kanun gereği mirasçılara intikal eder. Mirasçılar, yasal ya da atanmış mirasçı olmalarına bakılmaksızın, mirasbırakanın devredilebilen bütün hak ve borçları, terekedeki taşınır ve taşınmazların zilyetliği, kısaca terekenin tamamı üzerinde hak sahibi olurlar (MK m.599). Bu, miras hukukunda geçerli olan külli halefiyet ilkesinin sonucu ve gereğidir. ${ }^{33}$

$\mathrm{Bu}$ ilke gereğince bir mirasçı terekede bulunan malları, alacakları ve borçları bir bütün (kül) olarak kazanır. Yoksa mirasçının bunlardan bazılarını kabul, bazılarını reddetme yetkisi yoktur. Bir mirasçının mirası reddetmesi ancak reddi mirasın tamamını kapsadığı takdirde geçerlidir. ${ }^{34}$

\footnotetext{
$29 \quad$ Mecelle, md. 1075.

$30 \quad$ Mecelle, md. 1069.

31 Mecelle, md. 215.

32 Turgut Akıntürk - Derya Ateş, Medenî Hukuk (İstanbul: Beta Yayıncılık, 2018), 329. Ayrıntılı bilgi için bk. Serozan - Engin, Miras Hukuku, 125-145.

33 İnan vd., Türk Medeni Hukuku Miras Hukuku, 73, 482, 529; Akıntürk - Ateş, Medenî Hukuk, 355.

34 Akıntürk - Ateş, Medenî Hukuk, 355.
} 
98 RTEüirfD

Mirasbırakanın hayatta ve mirasa ehil olan bir tek mirasçısı varsa, mirasın tamamı bu mirasçıya geçer; bu mirasçı mirasın (terekenin) tamamına tek başına sahip olur. Ancak, bu durum çok sıklıkla söz konusu olmaz. Çoğunlukla mirasbırakanın birden çok mirasçısı olur. Eğer mirasbırakanın birden çok mirasçısı varsa, bu mirasçılar hep birlikte tereke üzerinde elbirliği (iştirak) halinde mülkiyet ${ }^{35}$ hakkına sahip olurlar. Medenî Kanun mirasçlların oluşturduğu bu topluluğu miras ortaklığı olarak isimlendirmektedir (m.640). Miras ortaklığı mirasın açıldığı anda kanundan ötürü, yani kendiliğinden doğar ve miras paylaşılıncaya kadar varlığını sürdürür. ${ }^{36}$

Medeni Kanun'da miras ortaklığının elbirliği halinde hak ortaklı̆̆ı şeklinde tanımlanması (m.640), tereke üzerinde mirasçıların hisseleri belli olmayacak şekilde hak sahibi oldukları anlamına gelmektedir. Başka bir ifade ile her ortağın (mirasçının) mülkiyet hakkı, mirasın tamamını kapsar. Bu itibarladır ki ortaklardan biri tek başına mirasın tamamı üzerinde bir işlem veya tasarrufta bulunamadığı gibi bir kısmı üzerinde de bulunamaz. Ancak bütün mirasçların muvafakati ile tereke üzerinde herhangi bir tasarrufta bulunulabilir. Bununla beraber MK m.677, mirasçının miras payını, paylaşımdan evvel üçüncü kişiye devrine olanak vermiştir. Bu temlik edilen şey, mirasın paylaşımından sonra mirasçıya verilecek tasfiye hissesidir. Üçüncü şahıs bu temlik işlemine dayanarak terekenin yönetimine karışamaz, mallardan yararlanamaz ve paylaşıma müdahalede bulunamaz. Onun hakkı, ancak devreden mirasçıya ayrılan payın talebine ilişkindir. ${ }^{37}$

Miras ortaklığı, kural olarak mirasın paylaşılmasına kadar devam eder. Miras ortaklığı, Medenî Kanundaki düzenlemeler uyarınca mirasın paylaşılması veya elbirliği mülkiyeti paylı mülkiyete 38 dönüştürmekle ya da miras ortaklığı başka bir ortaklığa çevrilmekle sona ermiş olur. ${ }^{39}$

\section{Rızâî-Kazâî Açıdan Mirasın Paylaşılması}

Mirasın iki aşamadan oluştuğu ifade edilmiş ve birinci aşaması olan mirasın vârislere intikali ve böylece vârisler arasında oluşan miras ortaklığından

35 Elbirliği Mülkiyeti, MK m.701'de belirtildiği üzere kanun veya kanunda öngörülen sözleşmeler uyarınca oluşan topluluk dolayısıyla mallara birlikte malik olanların mülkiyeti, elbirliği mülkiyetidir. Elbirliği mülkiyetinde ortakların belirlenmiş payları olmayıp her birinin hakkı, ortaklığa giren malların tamamına yaygındır.

36 İnan vd., Türk Medeni Hukuku Miras Hukuku, 74, 483, 529-530; Akıntürk - Ateş, Medenî Hukuk, 358.

37 İnan vd., Türk Medeni Hukuku Miras Hukuku, 529-530.

38 MK m.688'de paylı mülkiyet şöyle tanımlanmıştır: Paylı mülkiyette birden çok kimse, maddî olarak bölünmüş olmayan bir şeyin tamamına belli paylarla maliktir. Başka türlü belirlenmedikçe, paylar eşit sayılır. Paydaşlardan her biri kendi payı bakımından malik hak ve yükümlülüklerine sahip olur. Pay devredilebilir, rehnedilebilir ve alacaklılar tarafından haczettirilebilir.

39 Hatice Tolunay Ozanemre Yayla, Mirasın Paylaşılması (Ankara: Gazi Üniversitesi Sosyal Bilimler Enstitüsü, Doktora Tezi, 2011), 11-12. 
bahsedilmişti. Bu bölümde ise ikinci aşaması olarak kabul ettiğimiz vârislerin terekedeki hisselerinin kendilerine özgülenmesi yani mirasın paylaşılması/taksimi ele alınmaktadır.

\section{1. İslâm Hukukuna Göre}

Mirasın paylaşılması, kaynaklarda mirasla ilgili hükümlerin ele alındığı "ferâiz" veya "miras" denilen bölümde ele alınmadığı gibi müstakil bir bölüm olarak da konu edilmiş değildir. Mirasın paylaşılması, şâyi hisseli ortak malların paylaşılmasını konu edinen "kısmet" (taksim) bölümü altında diğer müşterek malların paylaşılmasıyla birlikte incelenmiştir. ${ }^{40}$

Mezhepler, taksimi farklı bakış açılarına göre çeşitli şekillerde kısımlara ayırmışlardır. Bu da sonuç bakımından benzer fakat tasnif ve isimlendirme yönünden farklı taksim türlerinin ortaya çıkmasına sebep olmuştur. ${ }^{41}$ Hanefilere göre şâyi hisseli malların taksimi, taksim yolu/kanalı bakımindan rızâî ve kazâấ; taksim, yöntemi bakımından ise tefrik ve cem' şeklinde kısımlara ayrılmıştır. Kısmet-i tefrik, müşterek bir malın her cüzüne şâyi olan ortaklık hisselerini, belli kısımlarda taayyün edecek biçimde taksimine denir. Örneğin iki kişi arasında ortak olan bir arsanın ikiye taksim edilmesi gibi. Kısmet-i cem' ise müşterek malların ortakların paylarına göre kısımlara ayrılmasına ve bölünen malın her ferdinde şâyi olan hisselerin birer kısımda toplanmasına denir. Örneğin üç kişi arasında ortak olan otuz koyunun onar onar üçe taksim edilmesi gibi. ${ }^{42}$ Konumuz itibariyle burada mirasın paylaşma yolu olan rızâîkazâî taksimin mahiyeti, mevzu bahis edilmekte ve mezhepler arası ihtilaflara yer verilmeden sadece Hanefî mezhebinin uygulaması esas alınarak incelenmektedir.

\subsubsection{Rizâî Taksim}

Rızâî taksim, paydaşların (vârislerin) yargı yoluna başvurmadan kendi aralarında karşılıklı rıza ile yaptıkları veya hepsinin rızasıyla hâkimin yaptığı taksimdir. ${ }^{43}$ Söz konusu taksime, tüm ortakların rızasıyla olduğu için rızâî taksim denilmektedir. ${ }^{44}$

40 Kâsânî, Bedâ'i'u's-sanâ'i', 9/141; İbn Rüşd, Bidâyetü'l-müctehîd, 681; Nevevî, Ravzatü't-tâlibîn, 8/181; Mer'î b. Yûsuf, Delîlü't-tâlib, 341; Koşum, İslâm Hukukunda Taksim, 9-12.

41 Bu tasnif ve isimlendirmeler için bk. Vehbe ez-Zühayli, el-Fıkhü'l-İslâmî ve edilletuhu (Dımeşk: Darü'l-Fikr, 1405/1985), 5/660-664; Koşum, İslâm Hukukunda Taksim, 18-32.

42 Kâsânî, Bedâ'i'u's-sanâ'i', 9/151; Mecelle, md. 1115. Ayrıntılı bilgi için bk. Aktan, Mukayeseli İslâm Miras Hukuku, 258-264; Koşum, İslâm Hukukunda Taksim, 23-25.

43 Mecelle, md. 1121; Ali Haydar Efendi, Dürerü'l-hükkâm, 3/343; Bilmen, Hukuk-ı İslâmiyye, 7/143; Adem Çakır, “Osmanlı Devleti'nde İslam Miras Hukukuna Uymayan Tereke Paylaşımları Üzerine Bir Çalışma”, Uluslararası II. Türk Hukuk Tarihi Kongresi, ed. Fethi Gedikli (İstanbul: Onikilevha Yayıncilık, 2016), 1/134-135.

44 Kâsânî, Bedâ'i'u's-sanâ'i', 9/148; Bilmen, Hukuk-ı İslâmiyye, 7/143; Aktan, Mukayeseli İslâm Miras Hukuku, 257; Koşum, İslâm Hukukunda Taksim, 18. 


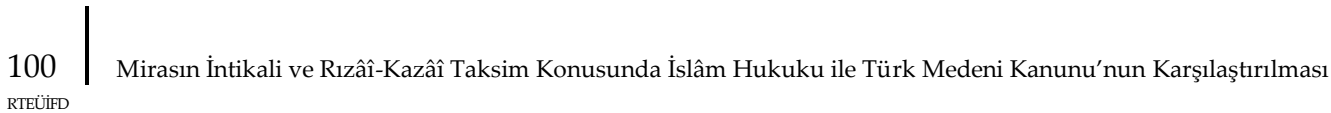

Rızâî taksim, ortakların karşılıklı rızalarına dayalı olduğundan öncelikle tercih edilmesi gereken ve de daha geniş uygulama imkânı bulunan taksim yoludur. ${ }^{45}$ Rıâ̂î taksimin geçerli olabilmesi bazı şartlara bağlıdır. Bunlar iki şart ile sınırlandırılabilir: ${ }^{4}$

1. Bütün ortakların taksime razı olması gerekir.

Vârislerin mahkemeye başvurmaksızın kendi aralarında taksimi icra edebilmeleri için tamamının muvafakati yani taksime rıza göstermeleri şarttır. Ancak bazen vârisler arasında rıza ehliyeti (tam eda ehliyeti) olmayan çocuk, mecnun veya ma'tûh bulunabilir.

Ortaklar arasında rıza ehliyetine sahip olmayan küçük, mecnun veya ma'tûhun bulunması durumunda rıâ̂î taksim, bunların veli veya vasîlerinin hazır bulunup onların menfaatine olacak şekilde taksimi onaylamasıyla mümkün olabilir. Aksi takdirde yapılacak taksim geçersizdir. Veli veya vasîlerinin olmaması durumunda hâkim tarafından bunlara vasî tayin edilebilir veya hâkim onların vasîsi sıfatıyla taksime iştirak edebilir. Rıâ̂î taksim de olsa çocuğun, mecnunun veya ma'tuhun istihkakının verilmesi gerekmektedir. Veli veya vasîlerinin, onların zararına olacak bir tasarrufu geçerli değildir. ${ }^{47}$

2. Taksimde bütün ortakların hazır bulunması gerekir.

Rızâî taksim bütün ortakların rızası ile gerçekleşen bir taksimdir. Bu nedenle bütün ortakların ya bizzat kendilerinin ya da vekillerinin taksimde hazır bulunmaları gerekmektedir.

Şayet ortaklardan biri gaip olur diğer vârisler de gaibin vekilinin hazır olmadığ bir durumda kendi aralarında onun da payını ayırarak taksim yapsalar bu taksim

45 Örneğin, taksime konu olan malın paylaştırılması her iki tarafa da zarar veriyorsa bu durumda kazâî taksim icra edilemezken rızâî taksim edilebilir. Kâsânî, Bedâ'i'u's-sanâ' $i^{\prime}$, 9/148. Taksime konu olan mallar iki veya daha fazla cins ise cem' yoluyla kazâi taksim icra edilemezken rıaî yolla edilebilir. Kâsânî, Bedâ'i'u's-sanâ'i', 9/151-152.

46 Rızâî taksimin geçerli olması için kaynaklarda başka şartlar zikredilse de bunların yukarıdaki iki şart içerisinde değerlendirilmesi mümkün olduğundan bunlar ayrı şartlar olarak değerlendirilmemiştir. Bunlardan biri, paylaşmayı icra edecek kişilerin "ehliyet" ile "mülk veya velayet" sahibi olmalarıdır. Ehliyet ile bu kimselerin akıl sahibi olmaları, "mülk veya velayet sahibi olmaları" ile de paylaşmaya konu olan mala mâlik olmaları veya mâlikin küçük veya mecnun olması durumunda onlar adına paylaşmayı icra edeceklerin velayet yetkisine sahip olmaları kastedilmektedir. Bir diğeri de paylaşmayı icra edecek tarafların "rıza ehliyetine sahip olmaları" dır. Bununla da bu kişilerin akıllı ve baliğ olmaları kastedilir. Bütün bu şartların "Bütün ortakların taksime razı olması gerekir." şartı bağlamında değerlendirilmesi mümkündür. Bu şartlar için bk. Kâsânî, Bedâ'i'u's-sanâ'i', 9/145; Zühayli, el-Fıkhü'l-İslâmî, 5/665-667.

47 Kâsânî, Bedâ'i'u's-sanâ'i', 9/153-154; Mevsilî, el-İhtiyâr, 2/88; İbn Âbidîn, Reddü'l-muhtâr, 9/427; Mecelle, md. 1128; Ali Haydar Efendi, Dürerü'l-hükkâm, 3/343, 360-362. 
gayrı nafiz (mevkuf) olur. ${ }^{48}$ Gaip bu durumu öğrendiğinde taksimi onaylarsa taksim geçerli, onaylamaz ise geçersiz olur. ${ }^{49}$

Rızâî taksim de olsa ortak malın paylaşılmasında asıl olan ortaklardan her birinin şâyi hisseli maldan hakkı olanı almasıdır. Ancak anlaşmaları durumunda tarafların diledikleri gibi tasarrufta bulunmaları da mümkündür. ${ }^{50}$ Buna göre vârisler, ferâiz hesaplamalarında kendilerine düşen hisseden daha az veya daha fazla bir mal paylaşımında bulunabilirler. Ancak şunu ifade etmek gerekir ki rızâî taksim vârislerin, Şârî'in naslarda beyan ettiği hisselere mukabil bir düzenlemede bulunmaları değil, aksine Şârî'in takdir ettiği şekilde fevren ve zorunlu olarak kendi mülkiyetlerine intikal eden şâyi hisseli hakları üzerinde tasarrufta bulunmaları demektir. Bu minvalde ortaklardan birinin diğer vârisler lehine terekedeki tüm haklarından veya bir kısmından feragat etmesi mümkündür. Bu feragat bir nevi hibedir. Bunun yanında vârislerden birinin bir bedel karşılığı mirastan çıkması da söz konusu olabilir ki buna tehârüc denir. ${ }^{51}$

Rızâî taksim şartlarına uygun olarak vaki olduktan sonra tüm ortakları bağlar. Dolayısıyla her ortak payına düşeni kabzettikten sonra artık taksimin iptalini talep edemez. Ancak taraflar karşılıklı rıza yani ikâle yoluyla taksimi iptal edebilirler. ${ }^{52}$

\subsubsection{Kazâî /İcbârî Taksim}

Ortak mülkiyetin paylaşılmasında asıl olan ortakların karşılıklı rızaya bağlı olarak paylaşımı gerçekleştirmeleridir. Ancak tarafların uzlaşmaları her zaman mümkün olmadığı gibi bazılarının paylaşımdan kaçınmaları da söz konusu olabilmektedir. İşte bu gibi durumlarda ortaklardan/vârislerden biri veya birkaçının talebi üzerine hâkimin cebren yaptığı taksime kazâî veya icbârî taksim denir. Bu kısmet, bizzat hâkim tarafından yapılabildiği gibi hâkimin tayin edeceği bir kassam

48 Şayet taksime konu olan müşterek mal, mislî yani ortakların tek başına hissesini ifrazına imkân tanıyan bir mal olursa bu durumda gaibin onayına bağlı kalmaksızın taksim nafiz olur. Bk. Ali Haydar Efendi, Dürerü'l-hükkâm, 3/360-361.

49 Kâsânî, Bedâ'i'u's-sanâ'i', 9/153-154. Ayrıca bk. İbn Âbidîn, Reddü'l-muhtâr, 9/427; Mecelle, md. 1126; Bilmen, Hukuk-ı İslâmiyye, 7/141; Ali Haydar Efendi, Dürerü'l-hükkâm, 3/ 360-361.

50 Kâsânî, Bedâ'i'u's-sanâ'i', 9/142-143, 148; Mecelle, md. 1135; Koşum, İslâm Hukukunda Taksim, 18-19.

51 Tehârüc, mirasçılardan birinin, diğer mirasçılardan biri, birkaçı veya tamamıyla sulh ederek belirli bir mal karşılığında miras işleminden çekilmesi anlamına gelir. Bu sulh bir açıdan bey' sayılır. Sulh bedelinin miras hissesinden az ya da çok olması mümkündür. Şayet sulh mirasçların tamamı ile yapılmışsa taksim işlemi, teharuç edenin hissesi çıkarılarak kalan mirasçıların hisselerinin toplamı üzerinden hesaplanır. ${ }^{51}$ Şayet biri veya birkaçı ile sulh yapılmışsa teharuç edenin hissesi, sulh yaptığı varis veya varislere sulh bedelindeki hisselerine göre verilir. Mevsılî, el-İhtiyâr, 4/523; Ali Haydar Efendi, Dürerü'l-hükkâm, 4/52; Bilmen, Hukuk-ı İslâmiyye, 7/138; Benzer bir değerlendirme için bk. Çakır, “Osmanlı Devleti'nde İslam Miras Hukukuna Uymayan Tereke Paylaşımları Üzerine Bir Çalışma”, 135.

52 Koşum, İslâm Hukukunda Taksim, 19-20. 
102

Mirasın İntikali ve Rızâî-Kazâî Taksim Konusunda İslâm Hukuku ile Türk Medeni Kanunu'nun Karşılaştırılması RTEÜIFD

tarafından da yapılabilir. ${ }^{53}$ Mahkeme yoluyla mirasın paylaşılabilmesi için bazı şartlar gerekir. Bunlar;

1. Ortakların hâkimden taksim talebinde bulunması gerekir.

Hâkimin paylaştırmayı re'sen gerçekleştirme yetkisi bulunmaz. Bu nedenle taraflardan birilerinin talebi şarttır. Paylaştırmayı ortaklardan birinin veya tamamının talep etmesi mümkündür. ${ }^{54}$

Ebû Hanife' ye göre taksimi istenen mal, ev ve arazi gibi gayrı menkul bir mal ise ortakların sadece taksim talebinde bulunması yeterli olmaz. Ayrıca taksimini talep ettikleri malın kimden miras kaldığını ve mirasçıların sayısını ispat etmeleri (beyyine) de gerekir. Taksimi istenen müşterek mal, menkul mal ise talep edenlerin mücerret ikrarları yeterlidir. Ayrıca kimden miras kaldığı ve mirasçıların sayısını ispat etmeleri istenmez. ${ }^{55}$

Ebû Yûsuf ve Muhammed eş-Şeybânî'ye göre ise taksimi istenen mal ister menkul ister gayrı menkul olsun ortakların mücerret ikrarları yeterli olur. Kendilerinden ayrıca beyyine istenmez. Ancak onlara göre bu durumda taksim kararı veren hâkim, karar metnine bu taksim kararını beyyinesiz olarak mücerret ikrarlarıyla verdiğini belirtmelidir. Bunlara göre şayet vârislerin bazıları gaip veya aralarında çocuk varsa ve gayrı menkul malın tamamı veya bir kısmı da bunların elindeyse bu durumda talepte bulunan mirasçılardan beyyine istenir. ${ }^{56}$

2. Taksimin bütün ortakların zararına olmaması gerekir.

Müşterek malın taksim edilmesi, ortakların yararına olabildiği gibi zararına da olabilir. Şayet mal taksimi, ortakların tamamının menfaatine ise hâkim taksimi icra eder, zararına olacaksa taksimi icra edemez. ${ }^{57}$ Ancak bazen taksim bir tarafın yararınayken diğer tarafın zararına olabilir. Bu durumda şayet hissesi fazla olan taraf taksim talebinde bulunmuşsa ittifakla taksim caiz, şayet hissesi az olan taraf taksim

53 Kâsânî, Bedâ'i'u's-sanâ'i', 9/142-143, 148; Mecelle, md. 1122, 1129, 1130; Ali Haydar Efendi, Dürerü'lhükkâm, 3/ 343; Bilmen, Hukuk-ı İslâmiyye, 7/141-142-143; Koşum, İslâm Hukukunda Taksim, 20.

54 Bilmen, Hukuk-ı İslâmiyye, 7/141.

55 Kâsânî, Bedâ'i'u's-sanâ'i', 9/154-156; İbn Âbidîn, Reddü'l-muhtâr, 9/429-431.

56 Şayet taksim esnasında gaip olan varis, taksimi öğrenir ve taksimi aynen onaylarsa, taksim geçerli olur. Ancak inkâr ederse sadece ikrarla icra edilmiş taksim bozulur fakat beyyine ile ispat edilmiş taksim ise onun hakkında nafiz olur, bozulmaz. Bk. Kâsânî, Bedâ' $i^{\prime} u^{\prime} s-s a n \hat{a}^{\prime} i^{\prime}$, 9/154-156; Mevsılî, el-İhtiyâr, 2/89; İbn Âbidîn, Reddü'l-muhtâr, 9/429-431.

57 Taksimin ortaklara fayda veya zarar vermesi, müşterek malın niteliğiyle ilgili bir durumdur. Şayet müşterek mal, ölçülü, tartılı veya aded-i mütekarip mallardan ise bu malların taksimi bütün ortakların yararına olacaktır. Çünkü bu durumda her bir ortak kendisine tahsis edilmiş maldan dilediği şekilde tasarrufta bulunabilecektir. Şayet tek bir elbise, dükkân, hayvan, duvar, küçük bir oda gibi bir mal ise bunların bölünmesi ortakların tamamına zarar verecektir. Çünkü bölünmekle bunlardan beklenen menfaat ortadan kalkar. Bk. Kâsânî, Bedâ'i'u's-sanâ'i', 9/148. 
talebinde bulunmuşsa Hâkim eş-Şehîd' in (ö. 334/945) aktarımına göre taksim caizken Kudûrî'nin (ö. 428/1037) aktarımına ${ }^{58}$ göre ise caiz değildir. ${ }^{59}$

3. En az iki vârisin mal taksiminde hazır bulunması gerekir.

Vârislerin tamamının hâkimin taksimi sırasında hazır bulunması şart değildir. Vârislerden bazıları taksim sırasında gaipse veya vârisler arasında çocuk bulunuyorsa hâkimin taksimi icra etmesi için ortaklardan en az iki kişinin hazır bulunması yeterlidir. Böyle bir durumda hâkim taksimi icra eder, gaip ve çocuk olan ortağın payını ayırarak koruması için birini vekil/vasî tayin eder. Ancak taksim sırasında ortaklardan sadece biri hazır olup, diğer ortaklar gaipse bu durumda hâkim taksimi icra edemez. ${ }^{60}$

Kazâi taksim, yukarıda yapılan tanımdan da anlaşılacağı üzere şâyi hisseli ortak malın/mirasın paydaşlara hâkim yoluyla paylaştırılmasını ifade etmektedir. Yoksa mirasın ferâiz ilminde belirlenen hisselere göre taksim edilmesi anlamına gelmez. ${ }^{61}$ Zira ister rızâî ister kazâî olsun taksimde aslolan ferâizdeki hisselerine göre her hak sahibine hakkının verilmesidir. Ancak nasıl ki rıâ̂i taksimde bütün ortakların anlaşmaları durumunda bazı vârislerin ferâiz hisselerinin tamamı veya bir kısmından feragat etmeleri mümkünse, kazâî taksimde de benzer şekilde ortakların tamamının ${ }^{62}$ veya bir kısmının anlaşmaları durumunda ferâiz hisselerinin tamamı veya bir kısmından diğerlerinin lehine feragat etmeleri mümkün olabilir. Ancak tarafların aksi bir iradesi yoksa hâkim ferâizde belirlenen hisselerine göre taksimi icra eder. ${ }^{63}$

58 Ebü'l-Hüseyn Ahmed b. Muhammed b. Ahmed el-Kudûrî, el-Muhtasar, thk. Kamil Muhammed Muhammed 'Uveyda (Beyrut: Darü'l-Kutubi'l-İlmiyye, 1418/1997), 227.

59 Zararın taksime engel olup olmadığı hususunda söylenenler, tefrik yöntemiyle gerçekleştirilen taksim hakkındadır. Bir diğer taksim yöntemi olan cem' taksiminde ise taraflara zararın dokunması söz konusu olmaz. Zira cem’ taksimi misli veya fertleri arasında fahiş farkın olmadığı tek cins mallarda icra edilen taksimdir. Bunların taksiminde ise taraflara zararın dokunması muhtemel değildir. Bk. Kâsânî, Bedâ'i'u's-sanâ'i', 9/148-153; Mevsilî, el-İhtiyâr, 2/90.

60 Ortaklardan birinin gaip olması durumunda gayrı menkul ortak bir malın hâkim tarafından taksim edilmesi mirasa özeldir. Taksim talebinde bulunan ortaklar, müşterek mülkiyeti satım gibi akitle veya bir sebep zikretmeksizin mutlak olarak ikrar etmeleri durumunda eğer ortaklardan birileri gaipse hâkim taksimi icra etmez. Tüm ortakların bizzat veya vekillerinin hazır bulunması şartı aranır. Serahsî, el-Mebsût, 15/12; Kâsânî, Bedâ'i'u's-sanâ'i', 9/154-156; Mevsılî, el-i̇htiyâr, 2/89.

61 Kazâî taskimin, "ferâiz ilminde belirlenen hisselere göre taksim edilmesi" anlamındaki kullanım için bk. Ahmet Yaman - Halit Çalış, İslâm Hukuku (Ankara: Bilimsel Araştırma Yayınları, 2018), 396.

62 Hâkimin icra ettiği taksimde şayet vârislerin uzlaşması söz konusu olursa bu durumda hâkim rızâî taksimin şartlarına riayet ederek taksimi gerçekleştirir. Buna rızâî taksim de denilebilir. Bk. Mecelle, md. 1121; Ali Haydar Efendi, Dürerü'l-hükkâm, 3/343; Bilmen, Hukuk-ı İslâmiyye, 7/143.

63 Kâsânî, Bedâ'i'u's-sanâ'i', 9/142-143, 148; Bilmen, Hukuk-ı İslâmiyye, 7/143; Koşum, İslâm Hukukunda Taksim, 20. 
\begin{tabular}{l|l}
104 \\
RTEÜirl
\end{tabular}

Miras, vârislerin uzlaşmaları ile paylaşılmaz ve mahkeme yoluyla da taksim mümkün olmazsa vârislerin miras üzerindeki ortaklıkları devam eder. Bu durumda taraflar eşyadaki menfaatlerin taksimi anlamına gelen özel bir rejim yani mühayee ile ortak mülkiyetleri olan mirastan yararlanabilirler. ${ }^{64} \mathrm{Bu}$ da ya mekân ya da zaman bakımından ortak malın menfaatinin paylaşılması şeklinde olabilir. Mekân bakımından mühayeede ortakların her biri, örneğin iki katlı bir eve sahip iseler, evin bir katında ya bizzat kendileri oturarak veya kendilerine düşen tarafı ücret karşılı̆̆ kiraya vererek müşterek maldan faydalanabilirler. Zaman bakımından mühayeede ise ortaklar, örneğin birer yıl arayla oturmak veya bu süre zarfında ücret karşılığında kiraya vermek şeklinde müşterek maldan yararlanabilirler. ${ }^{65}$

\subsection{Türk Medeni Kanunu'na Göre}

Mirasın paylaşımı mirasçılar arasında yasa gereği meydana gelmiş miras ortaklığına son vermek için miras payının ayrılması ve onların mirasçılara özgülenmesidir.

Mirasın paylaşımını düzenleyen kuralların büyük bir kısmı yorumlayıcı ve tamamlayıcı hukuk kurallarıdır. Bu nedenledir ki mirasın, mirasçıların anlaşmaları suretiyle paylaşılması esas olarak kabul edilmiştir. Bununla birlikte mirasbırakan, mirasın nasıl paylaşılacağına, hangi malların hangi mirasçılara ait olacağına dair emir ve arzularını ölüme bağlı bir tasarruf olarak bildirmekle mirası düzenleyebilir. Mirasbırakanın böyle bir tasarrufta bulunmaması ve mirasçıların da mirasın paylaşımında anlaşamamaları halinde paylaşma tarafların bir dava ile talep etmesi üzerine hâkim tarafından yapılır. Paylaşma davası veya "izale-i şüyu davası" adı verilen dava sonucunda hâkimin yaptığı paylaşımı mirasçılar kabul etmek zorundadir.

Medeni Kanun'un paylaşıma dair hükümleri iki ilkeden hareket edilerek vazedilmiştir. Bunlardan ilki "paylaşma özgürlüğü (serbestisi)" ilkesi olup, mirasçıların terekeyi diledikleri gibi paylaşmalarını, hâkimin bu paylaşıma karışmamasını ifade eder (MK m.646 II). İkincisi ise "mirasçıların hukukça eşitliğii" ilkesidir. Bu ilke de mirasın, esas itibariyle mirasçılar arasında aynı kurallara göre paylaşılmasını ifade eder (MK m.648/I). ${ }^{66}$

\subsubsection{Mirasçıların Anlaşarak Terekeyi Paylaşması}

MK m.646. gereğince, mirasçllar aralarında diledikleri gibi, örneğin birisi terekedeki taşınırları, diğeri taşınmazları, üçüncüsü ticari bir işletmeyi alarak veya

64 Koşum, İslâm Hukukunda Taksim, 20.

65 Bk. Kâsânî, Bedâ'i'u's-sanâ'i', 9/172-173; İbrahim Kâfi Dönmez, "Mühâyee", Türkiye Diyanet Vakfi İslâm Ansiklopedisi (İstanbul: TDV Yayınları, 2006), 31/510.

66 İnan vd., Türk Medeni Hukuku Miras Hukuku, 544. 
bütün terekeyi satıp nakde çevirdikten sonra yahut mahalli örf ve adetlere veya aile arasındaki ilişkiler ve gelenekleri dikkate alarak, ${ }^{67}$ terekeyi paylaşabilir. Mirasçılar, aralarında yapacakları bir yazılı paylaşma sözleşmesi ile veya elden paylaşma ile terekeyi paylaşabilirler. Mirasçıların diledikleri gibi bir paylaşıma gidebilmeleri ancak oybirliği ile karar vermelerine bağlıdır.

Şayet mirasçılar arasında küçük veya kısıtlılar varsa paylaşma, bunlar adına yasal temsilcileri tarafından yapılır. Hatta vesayet altındaki küçük veya kısıtlının vasisi, MK m.462/9 gereğince, terekenin paylaşımı için sulh hâkiminden izin almak mecburiyetindedir. ${ }^{68}$

İrade özgürlüğü (muhtariyeti) ve paylaşmanın özelliğini dikkate alarak, mirasçılar arasında paylaşım serbestisini koyan Medeni Kanun, bu ilkeyi iki halde sınırlandırmıştır. Bunlar: 1. Mirasbırakanın paylaşım kurallarını koyması. 2. Paylaşıma hâkimin katılımı (iştiraki).

\subsubsection{Mirasbırakanın Paylaşım Kurallarını Koyması}

MK m.647 mirasbırakana, vasiyet veya miras sözleşmesi ile terekenin nasıl pay edileceğini ve payların nasıl oluşturacağını tayin ve tespit etmek konusunda tam bir yetki vermektedir. Bundan dolayı mirasbırakan bu yetkiye dayanarak terekesinin ölümden sonra mirasçıları arasında arzusuna uygun olarak paylaşımını emredebilir veya her birine kendi belirleyip özgülediği payı bırakabilir.

Mirasbırakanın ölüme bağlı tasarrufu ile koyduğu bu kurallar, esas itibariyle mirasçıları bağlayıcıdır. Bununla beraber, mirasçılar aralarında oybirliği sağlayarak, bu kurallara uymayıp iradi veya yasal bir paylaşmayı tercih edebilirler. Bunu önlemek için mirasbırakanın, vasiyeti yerine getirme görevlisi (tenfiz memuru) tayin etmesi gerekir. Çünkü mirasçllar vasiyeti yerine getirme görevlisi tayinine itiraz edemezler. Mirasbırakanın koyacağı paylaşım kuralları saklı payları ihlal etmemelidir. ${ }^{69}$

67 Medeni Kanun'un "paylaşma özgürlüğü (serbestisi)” ilkesi gereğince mirasçılar oy birliği ile diledikleri şekil veya bir uygulamayı esas alarak mirası paylaşabilirler. Buna İslâm miras uygulaması da dâhildir. Ancak mirasçılar arasında oybirliği sağlanmadığı takdirde mahkeme tarafından icra edilecek miras paylaşımında hâkim MK hükümlerini icra eder. Buna göre ülkemiz açısından İslâm miras uygulaması sadece tarafların uzlaştıkları ve bizzat kendilerinin gerçekleştirdiği paylaşımla mümkün olabilir. Ayrıca bk. Şakir Berki, "İslâm Miras Sistemi ile Medeni Kanun'un Miras Sistemi Arasındaki Farklar", Ankara Üniversitesi İlahiyat Fakültesi Dergisi 22/1 (1978), 2.

68 İnan vd., Türk Medeni Hukuku Miras Hukuku,545.

69 İnan vd., Türk Medeni Hukuku Miras Hukuku, 547-548. 
\begin{tabular}{l|l}
106 \\
RTEÜirD
\end{tabular} Mirasın İntikali ve Rızâî-Kazâî Taksim Konusunda İslâm Hukuku ile Türk Medeni Kanunu'nun Karşılaştırılması

\subsubsection{Paylaşıma Hâkimin Katılımı (İştiraki)}

Bu da iki şekilde olur.

1. Mirasçılar arasında çekişmenin (ihtilafın) bulunması halinde.

Mirasçılar mirasın paylaşımı tarzında, payların oluşturulmasında ve oluşan bu payların özgülenmesinde oybirliği sağlayamaz ise, aralarından birinin başvurusu üzerine paylaşma hâkim tarafından yapılır. Hâkim bu konuda yerel adetleri, mirasçıların kişisel durumları ile çoğunluğun arzularını dikkate alır (MK m. 650).

2. Üçüncü kişinin yararının bulunması halinde.

MK m.648 gereğince, mirasçılardan birinin payını üçüncü bir kişiye satması veya bir alacaklısının bu payı haczettirmesi yahut alacaklının mirasçı aleyhine aciz belgesi alması hallerinde mirasçının miras payı ile ilgisi kalmamış olduğundan, alacaklının talebi ile hâkim paylaşıma, mirasçının yerine geçmek üzere bir kayyım atar ve bu kayyım paylaşıma katılır ve alacaklının hakkını korur. Burada hâkim alacaklının değil, mirasçının yerine paylaşıma katıldığından onun temsilcisidir.

Medeni Kanun, mirasın paylaşımında ikinci ilke olarak "mirasçıların hukukça eşitliği"ni kabul etmiştir. ${ }^{70}$ MK m.646/I hükmündeki paylaşımda mirasçıların hukukça eşitliğinden kastedilen, bütün mirasçıların eşit miktarda miras paylarına sahip olmaları değil, cinsiyetleri, yaşları dikkate alınmadan mirasçıların aynı haklara sahip olmalarını, tereke üzerinde aynı yetkilere sahip olmalarını; başka bir deyişle mirasçıların aynı hukuk kurallarına tabi olmalarını ifade eder. ${ }^{71}$

\section{GENEL DEĞERLENDİRME VE SONUÇ}

İslâm miras hukuku ile Türk miras hukukuna göre mirasın intikali, intikalin genel esasları, miras ortaklığı, ortaklığın türü ve mirasın paylaşılma yolları hakkında genel bilgiler aktarıldı. Burada ise mezkûr konularla ilgili iki hukuk sistemi arasındaki benzerlik ve farklılıklara yer verilmektedir.

Her iki hukuk sisteminde de prensip olarak kişinin (murisin) ölümüyle birlikte geride biraktığı malvarlığı (tereke), vârislerine intikal eder. Bu intikal, İslâm miras hukukunda bir kişinin diğer bir şahsın yerine kaim olması anlamında mutlak halefiyet, Türk miras hukukunda ise Roma hukuku kaynaklı kurumlar olan küllî halefiyet ve cüz'î halefiyet türleri olarak benimsenmiştir.

70 Mirasçıların hukukça eşitliği ilkesi de kesin ve mutlak bir ilke değildir. Mirasbırakan ölüme bağlı tasarrufu ile mirasçıların hukukça eşitliği ilkesine bazı istisnalar koyabilir. Bk. İnan vd., Türk Medeni Hukuku Miras Hukuku, 551.

71 İnan vd., Türk Medeni Hukuku Miras Hukuku, 548-550. 
Türk miras hukukunda Küllî halefiyet ilkesi temel esas olarak kabul edilmiş (MK m.599) ancak bazı istisnai durumlarda da cüz'î halefiyet benimsenmiştir. Küllî halefiyet ilkesi gereğince mirasçılar, yasal ya da atanmış mirasçı olmalarına bakılmaksızın, mirasbırakanın ölümü ile mirası bir bütün olarak yani mirasbırakanın devredebilen bütün hak ve borçları ile kazanırlar. Bundan dolayıdır ki bu sistemde mirasbırakanın devredebilen haklarıyla birlikte borçlarının da (aktif ve pasifler) terekenin kapsamına girdiği kabul edilmiştir. Bu sisteme göre mirasçların mirasbırakanın borçlarına karşı sorumlulukları, terekeyle sınırlı olmayıp kendi kişisel malvarlıklarına da sirayet eden sınırsız bir sorumluluk şeklindedir. ${ }^{72}$ Cüz'̂̂ halefiyet ise bir kimsenin intikale elverişli belirli bir mal veya hakkının, diğer bir kimseye geçmesini ifade eder. Doktrinde cüz'î halefle kastedilen vasiyet alacaklısıdır. Cüz'î haleflerin mirasbırakanın borçlarından kişisel malvarlıkları ile sorumlulukları bulunmamaktadır. Dolayısıyla bu kimseler gerçek veya teknik anlamda mirasçı kabul edilmezler. ${ }^{73}$

İslâm miras hukukunda benimsenen şekliyle halefiyet, Roma kaynaklı küllî veya cüz'î halefiyet kurumlarından biriyle tam olarak örtüştüğü söylenemez. Zira İslâm miras hukukunda terekenin kapsamına kişinin sadece aktif malvarlığı dâhildir. Borçlar (pasifler) ise tereke kapsamında sayılmayıp murisin teçhiz-tekfin masraflarından sonra öncelikli olarak terekeden karşılanması gereken alacak hakkı olarak kabul edilir. Bu nedenle mirasın intikali açısından halefiyet kavramının her iki hukuk sisteminde "bir başkasının yerine geçme" anlamında ortak bir paydada buluştukları söylenebilir.

Prensip olarak mirasın intikaliyle zorunlu miras ortaklığı oluşur. Ancak bu ortaklığın hangi tür mülkiyet oluşturduğu iki hukuk sisteminde farklılık arz eder. Miras ortaklığı, İslâm hukukuna göre şâyi hisseli (paylı) mülkiyet, Türk miras hukukuna göre ise elbirliği (iştirak) halinde mülkiyet olarak kabul edilmiştir.

Türk miras hukukunda miras ortaklığının elbirliği (iştirak) halinde mülkiyet şeklinde tanımlanması mirasçıların 1/2, 1/3, 1/4 gibi belirlenmiş payları olmaksızın terekenin tamamına hep birlikte malik olduğu anlamına gelmektedir. Dolayısıyla mirasın paylaşılması aynı zamanda miras üzerindeki hisselerinin belirlenmesini de gerektirmektedir. Türk Medeni Kanunu'na göre her ne kadar atanmış mirasçıların miras ortaklığındaki hisseleri belirlenmiş olsa da ilgili kanunların büyük bir çoğunluğu, yorumlayıcı ve tamamlayıcı hukuk kurallarıdır, emredici değildir. Ayrıca

72 İnan vd., Türk Medeni Hukuku Miras Hukuku, 71-77; A. Elif Ulusu Karataş, “Türk Miras Hukukunda Mirasın Kazanılmasında Halefiyet Türleri ve Türk Millerlerarası Özel Hukukundaki Yansımaları", Journal of Istanbul University Law Faculty 73/2 (Kasım 2016), 357-360.

73 İnan vd., Türk Medeni Hukuku Miras Hukuku, 72-75, 78; Karataş, “Mirasın Kazanılmasında Halefiyet Türleri", 372-374. 
MK, "paylaşma özgürlüğü (serbestisi)" ilkesi gereği mirasçllara terekeyi diledikleri gibi paylaşmaları ve ölüme bağlı tasarruf işlemleri olarak da mirasbırakana mirasçı atama ve terekenin nasıl paylaşılacağına dair kurallar koyma yetkisi tanımıştır. Buna göre mirasbırakan bu yetkiye dayanarak terekesinin ölümden sonra mirasçıları arasında arzusuna uygun olarak paylaşımını emredebilir veya her birine kendi belirleyip özgülediği payı bırakabilir. Mirasbırakanın mirasın paylaşılmasına dair bağlayıcı bir tasarrufu bulunmadığı takdirde mirasın paylaşılması öncelikli ve esas olarak uzlaşmaları durumunda mirasçıların kendilerine aittir. Oybirliği sağladıkları takdirde mirasçılar diledikleri şekilde mirası düzenleyebilir ve paylaşabilirler. Hâkimin bu hususta onlara karışma yetkisi yoktur. MK'daki tamamlayıcı hükümler ise bir anlaşmazlık vuku bulup tarafların mahkemeye başvurduklarında uygulanacak hükümleri ifade etmektedir. Buna göre mirasbırakanın mirası düzenlemeye yönelik ölüme bağlı bir tasarrufunun bulunmadığı ve mirasçıların da uzlaşma sağlayamadığı durumlarda mirasçılardan birilerinin talebi üzerine hâkim tarafından $\mathrm{MK}^{\prime} \mathrm{da}$ belirlenen hisselere ve kurallara göre miras paylaştırılır.

İslâm hukukuna göre ise mirasın intikalini düzenleyen kurallar, naslarla ve emredici hükümlerle sabittir. Dolayısıyla mirasçılar arasında 1/2, 1/3, 1/4 gibi kanunla (nasla) belirlenmiş şâyi yani mirasın her cüzüne ve zerresine yayılmış hisseli bir mülkiyet oluşur. Buna göre mirasın paylaşılması, İslâm hukuku açısından bir anlamda şâyi hisseli ortak malın paylaşılması olduğu söylenebilir. Nitekim İslâm hukuku kaynaklarında miras ve intikalle ilgili düzenlemeler "ferâiz" bölümünde ele alınırken, mirasın paylaşılması ise şâyi hisseli ortak malların paylaşılmasını konu edinen "kısmet" bölümünde ele alınmıştır. Hâl böyle olunca murisin mirasçı atama, miras hisselerini ve paylaşımını düzenleme yetkisi bulunmaz. Mirasçıların miras üzerindeki hakları kanunen (nasla) sabittir ve onların rızası olmaksızın da bu belirlenmiş haklarının değiştirilmesi mümkün olmaz.

İslâm hukukuna göre de mirasın, uzlaşmaları durumunda mirasçılar tarafından paylaşılmasının (rızâî taksim) esas olarak kabul edildiği söylenebilir. Mirasçılar paylaşım konusunda uzlaşma sağlayamaz veya bazıları paylaşımdan kaçınırsa bu durumda mirasçılardan birilerinin talebi üzerine hâkim tarafından miras paylaştırılır (kazâî taksim).

İslâm hukukuna göre mirasçıların uzlaştıkları takdirde mirası diledikleri gibi paylaşabilmeleri, miras üzerinde bir düzenlemede bulunmaları değil, aksine mirasın intikali ile oluşan şâyi hisseli mülkiyetleri üzerinde tasarrufta bulunmaları anlamına gelir. Başka bir deyişle söz konusu işlem mirasın düzenlenmesine yönelik bir işlem olmayıp aksine mülkiyeti kendilerine intikal etmiş müşterek malları üzerinde ortakların düzenlemede bulunmalarıdır. 




\section{KAYNAKÇA}

Akıntürk, Turgut - Ateş, Derya. Medenî Hukuk. İstanbul: Beta Yayıncılık, 24. Basım, 2018.

Aktan, Hamza. "Kısmet". Türkiye Diyanet Vakfi İslâm Ansiklopedisi. 25/258-259. Ankara: TDV Yayınları, 2002.

Aktan, Hamza. Mukayeseli İslâm Miras Hukuku. İstanbul: İşaret Yayınları, 1991.

Ali Haydar Efendi. Dürerü'l-hükkâm şerhu Mecelleti'l-ahkâm. 4 Cilt. Kostantiniyye: Matbaa-i Ebûzziyâ, 1330/1912.

Ali Haydar Efendi. Teshîlü'l-ferâiz. çev. Orhan Çeker. Konya: Tekin Kitabevi, ts.

Alkış, Alpaslan. "İslâm Miras Hukuku ile Türk Miras Hukukunun Varisler Yönüyle Karşılaştırılması". Çukurova Üniversitesi İlahiyat Fakültesi Dergisi 19/1 (2019), 6079. https://doi.org/10.30627/cuilah.541225

Apaydın, H. Yunus. "İbrâ". Türkiye Diyanet Vakfı İslâm Ansiklopedisi. 21/263-266. İstanbul: TDV Yayınları, 2000.

Arı, Abdüsselam. İslâm Miras Hukuku. İstanbul: M.Ü. İlahiyat Fakültesi Vakfı Yayınları, 3. Basım, 2020.

Bardakoğlu, Ali. “Iskat”. Türkiye Diyanet Vakfi İslâm Ansiklopedisi. 19/137-143. İstanbul: TDV Yayınları, 1999.

Berdîsî, Muhammed Zekeriyya. el-Miras. Kahire: Darü'n-Nahda el-Arabî, 1391/1971.

Berki, Şakir. "İslâm Miras Sistemi ile Medeni Kanunun Miras Sistemi Arasındaki Farklar”. Ankara Üniversitesi İlahiyat Fakültesi Dergisi 22/1 (1978), 1-15.

Berki, Şakir. "Kur'an'da Mîrâs Hukuku". Ankara Üniversitesi Hukuk Fakültesi Dergisi 38/1 (1981), 107-132. https://doi.org/10.1501/Hukfak_0000000804

Bilmen, Ömer Nasuhi. Hukuk-ı İslâmiyye ve Istılâhâtı Fıkhiyye Kâmusu. 8 Cilt. İstanbul: Bilmen Yayınevi, ts.

Buhârî, Alaüddin Abdülaziz b. Ahmed b. Muhammed. Keşfü'l-esrâr fì şerhi Usûli'lPezdevî. thk. Abdullah Mahmud Muhammed Ömer. 4 Cilt. Beyrut: Darü'1Kütübi'l-İlmiyye, 2. Basım, 1430/2009.

Cürcânî, Ebü'l-Hasen Alî b. Muhammed b. Alî es-Seyyid eş-Şerîf el-Hanefî. Şerhu'lFerâ'izi's-Sirâciyye. thk. Muhammed Muhyiddin Abddülhamid. Misır: Matbaa Mustafa Elbâbî Mahlebî ve Evladihi, 1323/1944. 
110 Mirasın İntikali ve Rızâî-Kazâî Taksim Konusunda İslâm Hukuku ile Türk Medeni Kanunu'nun Karşılaştırılması RTEÜİFD

Çakır, Adem. “Osmanlı Devleti'nde İslam Miras Hukukuna Uymayan Tereke Paylaşımları Üzerine Bir Çalışma". Uluslararası II. Türk Hukuk Tarihi Kongresi. ed. Fethi Gedikli. 1/ 115-137. İstanbul: Onikilevha Yayıncılık, 2016.

Dönmez, İbrahim Kâfi. "Mühâyee”. Türkiye Diyanet Vakfı İslâm Ansiklopedisi. 31/109111. İstanbul: TDV Yayınları, 2006.

Ebû Zehre, Muhammed. Ahkâmü't-terikât ve'l-mevâris. Kahire: Darü'l-fikri'l-Arabî, ts.

Erdoğan, Mehmet. Fıkıh ve Hukuk Terimleri Sözlü̆̆̈̈̈. İstanbul: Rağbet Yayınları, 1998.

Hacak, Hasan. "Müşâ'”. Türkiye Diyanet Vakfı İslâm Ansiklopedisi. 32/151-152. İstanbul: TDV Yayınları, 2006.

Hafîf, Ali. el-Milkiyye fi'ş-şerîati'l-İslâmiyye maa'l-mukârene bi'ş-şerâii'l-vaz'iyye. Kahire: Darü'l-fikri'l-Arabî, 1416/1996.

İbn Âbidîn, Muhammed Emîn b. Ömer b. Abdilazîz. Reddü'l-muhtâr ale'd-Dürri'lmuhtâr. thk. Abdulmecid Ta'me. 12 Cilt. Halebî. Beyrut: Dârü'l-Ma'rife, 1432/2011.

İbn Manzûr. Lisânü'l-Arab. thk. Abdullah Ali el-Kebîr vd. 6 Cilt. Kahire: Darü'l-Meârif, $1119 / 1707$.

İbn Rüşd, Ebü'l-Velîd Muhammed b. Muhammed b. Ahmed el-Kurtubî, Bidâyetü'lmüctehîd ve nihâyetü'l-muktesıd. thk. Heysem Cum'a Hilâl. Beyrut: Müessesetü'lMeârif, 1427/2006.

İnan, Ali Naim vd. Türk Medeni Hukuku Miras Hukuku. Ankara: Bilge Yayınevi, 9. Basım, 2015.

Karataş, A. Elif Ulusu. "Türk Miras Hukukunda Mirasın Kazanılmasında Halefiyet Türleri ve Türk Millerlerarası Özel Hukukundaki Yansımaları". Journal of Istanbul University Law Faculty 73/2 (Kasim 2016), 357-390.

Kâsânî, Alâüddin Ebû Bekr b. Mes'ûd b. Ahmed. Bedâ' 'i'u's-sanâ'i' fît tertîbi'ş-şerâ'i' thk. Ali Muhammed Muhammed Muavvaz - Adil Ahmed Abdülmevcud. 10 Cilt. Beyrut: Darü'l-Kütübi'l-İlmiyye, 2. Basım, 1424/2003.

Koşum, Adnan. İslâm Hukukunda Taksim. İstanbul: Marmara Üniversitesi, Sosyal Bilimler Enstitüsü, Yüksek Lisans Tezi, 1995.

Kudûrî, Ebü'l-Hüseyn Ahmed b. Muhammed b. Ahmed. el-Muhtasar. thk. Kamil Muhammed Muhammed ‘Uveyda. Beyrut: Darü'l-Kutubi'l-İlmiyye, 1418/1997.

Mâtürîdî, Ebû Mansûr Muhammed b. Muhammed b. Mahmûd. Te'vîlâtü Ehli's-sünne. thk. Mecdî Basellûm. 10 Cilt. Beyrut: Dârü'l-Kütübi'l-İlmiyye, 1426/2005. 
Mecelle-i Ahkâm-ı Adliyye. İstanbul: Matbaa-i Osmânî, 1300/1912.

Mer'î b. Yûsuf, Zeynüddîn el-Kermî. Delîlü't-tâlib li neyli'l-metâlib. b.y.: el-Mektebetü'1İslâmî, 2. Basım, 1389/1969.

Mevsılî, Ebü'l-Fazl Abdullah b. Mahmûd b. Mevdûd. el-İhtiyâr li ta'lili'l-Muhtâr. thk. Halid Abdurrahman el-Akk. 5 Cilt. Beyrut: Darü'l-Ma'rife, 1419/1998.

Meydânî, Abdülganî b. Tâlib b. Hammâde el-Guneymî ed-Dımeşkî. el-Lübâb fî şerhi'lKitâb. thk. Beşşâr Bekrî Arabî. Dımeşk: Dâr-1 Kubâ', 1424/2003.

Nesefî, Ebû'l-Berekât Abdullah b. Ahmed b. Mahmud. Medârikü't-tenzîl ve hakâ'iku'tte'vîl. thk. Yusuf Ali Büdeyvî. 3 Cilt. Dımeşk: Dâr-1 İbn Kesîr, 4. Basım, 1429/2008.

Nevevî, Ebû Zekeriyyâ Yahyâ b. Şeref b. Mürî. Ravzatü't-tâlibîn ve 'umdetü'l-mütteakîn. thk. Adil Ahmed Abdülmevcût - Ali Muhammed Muavvez. 8 Cilt. Suud: Dâr-1 Âlemi'l-Kütüb, 1423/2003.

Özay, Hilal. "İslâm Miras Hukukunun Özellikleri”. İslam Medeniyeti Araştırmaları Dergisi 3/2 (Aralık 2018), 203-224. https://doi.org/10.20486/imad.475629

Serahsî, Ebû Bekr Şemsü'l-eimme Muhammed b. Ebî Sehl Ahmed. el-Mebsût. 31 Cilt. Beyrut: Dârü'l-Ma'rife, ts.

Serozan, Rona - Engin, Baki İlkay. Miras Hukuku. Ankara: Seçkin Yayıncılık, 4. Basım, 2014.

Şeyh Nizâm - vd. el-Fetâva'l-Hindiyye. nşr. Muhammed Alî Beyzavî. 6 Cilt. Beyrut: Darü'l-Kütübi'l-i̇lmiyye, 1421/2000.

Şirbînî, Şemsüddin Muhammed b. Ahmed el-Hatîb. Muğni'l muhtâc ilâ ma'rifeti me'ânî elfâzi'l-Minhâc, thk. Muhammed Halil Aytânî. 4 Cilt. Beyrut: Darü'l-Marife, 1418/1997.

Tûrî, Muhammed b. Hüseyin b. Ali. Tekmiletü'l-Bahri'r-râik. nşr. Muhammed Alî Beyzavî. 9 Cilt. Beyrut: Darü'1-Kütüb'i-İlmiyye, 1418/1997.

Yaman, Ahmet - Çalış, Halit. İslâm Hukuku. Ankara: Bilimsel Araştırma Yayınları, 2018.

Yaran, Rahmi. "Halef". Türkiye Diyanet Vakfı İslâm Ansiklopedisi. 15/233-234. İstanbul: TDV Yayınları, 1997.

Yayla, Hatice Tolunay Ozanemre. Mirasın Paylaşılması. Ankara: Gazi Üniversitesi Sosyal Bilimler Enstitüsü, Doktora Tezi, 2011.

Yazıcı, Abdurrahman. "İslam Miras Hukuku ile Türk Medeni Kanunu Miras Sisteminin Mukayesesi". Ekev Akademi Dergisi 17/55 (Bahar 2013), 167-180. 
112 Mirasın İntikali ve Rızâî-Kazâî Taksim Konusunda İslâm Hukuku ile Türk Medeni Kanunu'nun Karşılaştırılması RTEÜIFD

Yazıcı, Abdurrahman. "İslâm Miras Hukuku ile Türk Medeni Kanunu Miras Sisteminin Mukayesesi". Ekev Akademi Dergisi 17/55 (Bahar 2013), 167-180.

Zerkâ, Mustafa Ahmed. el-Medhalü'l-fikhiyyü'l-âm. 2 Cilt. Dımeşk: Darü'l-Kalem, 2. Basim, 1425/2004.

Zühayli, Vehbe. el-Fıkhü'l-İslâmî ve edilletuhu. 8 Cilt. Dımeşk: Darü'l-Fikr, 2. Basım, 1405/1985. 